\title{
An Industry in Hard Times
}

\author{
By our Special Correspondent
}

The British motor industry has had a hard year, and the winter is still ahead.
Although more than a year has passed since the crisis measures of July 20,1966 , the British motor industry has not forgotten them. The combination of a freeze on wages and pressure on credit which $\mathrm{Mr}$ Wilson prescribed gave the industry the most uncomfortable autumn and winter it can remember. All the manufacturers suffered, but the worst hit was the British Motor Corporation, which declared 12,000 men redundant-and lost another 3,500 who decided that they would be better off elsewhere. BMC made a loss of $\mathfrak{f 7 . 5}$ million in the first six months of the financial year, and the second half report, still to come, will show only a small profit. There is little doubt that the other motor companies did badly over the same period, but they may have been saved some embarrassment by not having to produce a financial statement quite so soon.

The crisis at BMC has left a legacy. It has been traditional for $\mathrm{BMC}$ to take the largest share of the British market-usually around 40 per cent-but now its share is down to 32 per cent. Even this is not as bad as the 29 per cent to which it was reduced at the height of the crisis. People are now openly doubting whether $\mathrm{BMC}$ will be able to regain its dominance in the market without a new range of models. The Mini, now eight years old and continuing in virtually its original form, is too small as a basic unit. The 1100 model, the next in the range, is too expensive and the 1800 range has not been a success. By an unhappy blunder, BMC hardly competes in the 1.5 litre range, where Ford finds all its profits. In the bigger sizes, BMC has a positive embarrassment of models since it took over the Jaguar company, but all of them are beginning to look dated.

To some extent, BMC's troubles can be traced to an unwillingness to take full advantage of its size. Although the merger between the Nuffield organization and Austin took place 15 years ago, only in the last two or three years have the demarcation lines between the two organizations disappeared. Worse still, BMC still sees it as its duty to perpetuate the names of Riley and Wolseley-and others-by decorating perfectly honest Austins with the trappings of the more luxurious makes, walnut facias and all. It is surprising that supporters of the old marques are satisfied with such unconvincing imitations. Next year BMC will make a tentative step in the right direction by abolishing the distinction between Austin and Morris in the commercial vehicle field, but progress towards unification is slow.

The multiplicity of models is matched by a geographical diversity of factories. The whole British Motor Holdings group, including BMC, Jaguar and Pressed Steel-Fisher, controls 26 factories. There are at least two reasons for this; on the one hand, mergers have provided factories everywhere in Britain and, on the other, the group has been persuaded by the government to open new factories in depressed areasBathgate in West Lothian, and Llanelly in Wales. The results of this are unfortunate. To take one example, exhaust systems for the group are made at Morris Radiators plant in Oxford at the rate of 30,000 a week. But the actual silencers are made in Llanelly and taken across country by road for assembly into complete systems. After assembly, the systems are once again packed up and distributed by road to Longbridge and Cowley. Car doors are made in Llanelly, and transported to the main factories, again by road. This certainly introduces extra costs which a fully integrated plant avoids.

There are more optimistic signs. At Longbridge, $\mathrm{BMC}$ is building an integrated plant for the manufacture of engines. When finished, the new plant will be able to handle 5,000 engines a week on a highly automated assembly line controlled by computers. This development, which is to cost $£ 16$ million, will produce its first engines by the end of this year if there are no further delays-it is already four months behind schedule. Near Oxford, BMC has built a new spares warehouse as part of the service department. This project has cost $£ 6$ million, and should provide BMC with one of the most efficient spares services in the world.

These developments, and others, will be financed out of profits if BMC can start making them again. Much will depend on the economic climate. The other British motor companies will get only a small measure of satisfaction from BMC's discomfiture, principally because they are in almost as unhappy a position themselves. Ford's profit margins, once the wonder of other manufacturers, have been winnowed away over the years until they are little better than the rest. Only the Cortina in Ford's range is making money. Rootes, meanwhile, have found the experiment of going to Scotland to build their Imp range is not a success, and are currently ringing the changes on a basic model which is selling very slowly indeed. Vauxhall is troubled by labour stoppages and by the fear that its American owner, General Motors, favours a European marketing policy based on Opel, its German subsidiary, rather than on Vauxhall. Only Leyland-Triumph seems to have the models and the management to take advantage of the situation, and a government inspired merger between Leyland and $\mathrm{BMC}$ is beginning to seem increasingly possible. Certainly it is known that both the Ministry of Technology and the Industrial Reorganization Corporation have been trying to push in that direction, so far without success.

Perhaps this is why BMC is often heard plaintively to say that it is no more than the government's economic football, a phrase once reserved for the private steel companies. This is hardly fair-nobody has yet suggested that $\mathrm{BMC}$ should be nationalized, though it could conveniently be done without even a change of name. It is certainly true, however, that government pressure has damaged the industry by forcing it to expand in areas away from the centres of distribution. For all the fine phrases about the motor industry in Scotland-even repeated this week by an American, the new chief executive of Rootes - there is little doubt within the industry that the Scottish experiment has been a failure. 